\title{
Phenotypic Diversity of Haitian Benzolive (Moringa oleifera Lam.)
}

\author{
${ }^{1}$ Aristil Junior, ${ }^{2}$ Pierre Jonas Sanon, ${ }^{3}$ Dominique Lordé
}

1,2,3 Interdisciplinary Research Center for Agricultural Extension and Local Development (CREIVADEL), Notre Dame University of Haiti, Faculty of Agronomy,BP: HT 8110, Redon, Torbeck, South of Haiti.

Corresponding Author:junior2aris@gmail.com

\section{Manuscript Details}

Manuscript Submitted:04/01/2020

Manuscript Revised : 10/01/2020

Manuscript Accepted: 10/01/2020

Manuscript Published: 15/01/2020

\section{$\underline{\text { Available On }}$}

https://plantaescientia.website/ojs

\section{Cite This Article As}

Aristil J, Pierre J S \& Dominique L (2020) Phenotypic diversity of Haitian Benzolive (Moringa oleifera Lam.), Pla. Sci. 2020; Vol. 03 Iss. 01:01-06. DOI: https://doi.org/10.32439/ps.v3il.1-6

\section{$\underline{\text { Copyright }}$}

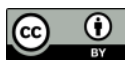

(C) The Author(s). 2018. Open Access

This article is distributed under the terms of the Creative Commons Attribution 4.0 International License

http://creativecommons.org/licenses/by/4.0/

$\underline{\text { Indexed In }}$

Crossref,Index Copernicus International (ICI), Directory of Research Journal Indexing (DRJI), Scientific Indexing Services (SIS), CiteFactor,

\section{ABSTRACT}

Moringa (MO) is a plant with great nutritional value distributed in almost all subtropical and tropical countries including Haiti. $\mathrm{MO}$ is relatively present in all departments of Haiti. But till now, there are no data available for the phenotypical diversities of Haitian MO. The current survey is aimed at evaluating the morphological diversity of Haitian MO. From June to September of 2018 year, 90 samples of MO were collected in the 10 departments of Haiti. Characters registered per plant were submitted to statistical analysis using IBM SPSS, version 22.0. Results revealed that Haitian MO grain yield (GY) were ranging from 0.20 to 3.26 t/ha. MO from Grand'Anse and South are significantly more yielded than the other districts ( $p<0.05$ ). MO grain yield was positively related with all registered characters. The two maximal GY correlations were observed mainly with number of branches plant $(\rho=0.74 ; \mathrm{p}<0.001)$ and number of pods per branch $(\rho=0.60 ; p<0.001)$. Haitian MO was classified into two separate clusters. MO of South, Southeast and Grand'Anse departments formed one cluster and the other departments constituted the largest one. The greatest genetic diversity was detected in MO from Southeast and West departments. Crossing materials from Southeast and West department is well recommended for creating possibly new accessions. Additional investigation regarding molecular classification is deeply required for better understanding the genetic diversity of Haitian MO.

Keywords: Moringa, Morphological diversity, Phenotypic diversity, Haiti 


\section{INTRODUCTION}

Moringa (MO), a plant with great medicinal and nutritional values, is from Himalaya (Leone et al., 2015). $\mathrm{MO}$ is actually distributed in almost all tropical and subtropical areas (Olson and Carlquist, 2001; Ogunsina et al., 2014). A total of 13 species of MO constitute the family Moringaceae (Leone et al., 2015). Among all, Moringa oleifera is the most documented (Yang et al., 2006).In Francophone countries, MO is calledMouroungue, Ben ailé, Moringa ailé, PoisQuénique, Néverdié and, particularly in Haiti, Benzolive (Gigon et al., 2004). MO is cultivated easily in arid as well as in semiarid region (Price, 1985). The tolerance of $\mathrm{MO}$ to water stress is mainly resulted from the morphological adaptation and the biochemical response of its vegetative parts (Teixeira et al., 2014). MO is mainly growing for its edible parts such as leaves, seeds and derived products like leaves powder and oil (Aristil, 2018). Environmental factors could affect leaves and seeds composition of MO (Anwar, 2007). MO is propagated by using its vegetative parts and by seeds (Leone et al., 2015). Leaves of $\mathrm{MO}$ are rich in vitamins, antioxidants and contain several cure-diseases properties. The nutritional and curative values of MO are worldwide documented (Dahiru et al., 2006; Chumark et al., 2008). Fruits, flowers and immature pods of $\mathrm{MO}$ are utilized as legumes (Anwar et al., 2006; Ouazine, 2017). MO wood is also an important source of paper (Thurber and Fahey, 2009). MO seed contain up to $40 \%$ of oil and after the oil extraction, the residues are used for water purification and facilitate the organic and inorganic materials sedimentation (Boucher, 2006; Foidl et al., 2001; Leone et al., 2016). MO is also growing in the Caribbean Region. Large genetic diversity was detected in MO materials from Panama, Belize, Mexico, Brazil and Venezuela (Shahzad et al., 2013). According to the literature available, Cuba is the first country with the most studies conducted on $\mathrm{MO}$ in the Caribbean Sea (Marrero Delange et al., 2014;Morton, 1991). In Haiti, MO is also present and grows mainly in agroforestery system. Meanwhile, data relative to the genetic as well as phenotypical diversities of $\mathrm{MO}$ accessions in Haiti are inexistent. Therefore the current survey is aimed at evaluating the phenotypical diversity of MO grows in Haiti for starting a breeding program with aims to increase leaves and seeds production.

\section{MATERIALS AND METHODS}

\section{Sampling}

From June to September 2018, a total of 90 trees of MO were investigated across the 10 departments of Haiti at rate of 9 per department. Moringa trees investigated had \pm 10 years old. All these plants were grown in agroforestry system with $4 \mathrm{~m} \mathrm{x} 4 \mathrm{~m}$ as distance of plantation corresponding to a plant density of 625 plants per hectare (Leone et al., 2015;Mendieta-Araica et al., 2013). Two categories of data were registered per plant: vegetative and productive characters. Some of these characters were collected in field and others in the laboratory of Université Notre Dame d'Haiti (UNDH). Productive and yield characters of each plant were registered in the laboratory of UNDH located at Torbeck, South, Haiti. Data registered in field included number of branches per plant (NBP), number of pods per branch (NPB). From each plant, a total of seven dried pods was selected and transported to the laboratory of UNDH for collecting data such as number of grains per pod (NGP), pod length (PL), pod circumference (PC), mass of 1 grain/seed (MlG) and mass of 100 grains/seeds (Ml00G). A Fisher balance was used for weighting MlG and Ml00G, which were weighted in gram. PL and CP were in $\mathrm{cm}$ and a scale meter was used for registering the last two traits. The grain yield (GY) of investigated $\mathrm{MO}$ tree was calculated by: $\mathrm{GY}(\mathrm{t} / \mathrm{ha})=\mathrm{MlG}$ (g) x NGP x NPB x NBP x $625 \div 1000,000$ (Aristil, 2019).

\section{Statistical Analysis}

Registered traits were submitted to statistical analysis using SPSS version 22.0 (Corp, 2013). Moringa traits were submitted firstly to one-ways analysis of variances (ANOVA) using provenance of materials as random and traits as fixed. 'Ryan-Einot-Gabriel-Welsch' test has been completed for establishing difference among means of each trait at ( $p<0.05$ ). Pearson's rank correlation coefficients $(\rho)$ were computed for all recorded traits and obtained results were used for computing a correlation matrix (Kwon and Torrie, 1964). Similarity among MO accessions was computed by Clustering Analysis (CA) using Hierarchical Cluster Method based on Euclideandistance(Crossa and Franco, 2004).

\section{RESULTS AND DISCUSSION}

$\mathrm{MO}$ is one of the most important plants cultivated in Developing country like Haiti. Phenotypic and genetic diversities could be detected among materials inside the Country/Haiti. Yet, there is, till now, no study conducted on phenotypical diversity of Haitian MO. Study conducted on Haitian MO are mainly related to fungal and aflatoxins contamination of seeds (Aristil et al., 2017; Aristil et al., 2019). The present survey was conducted to evaluate the morphological/phenotypical diversity of Haitian MO. A total of 8 morphological traits were registered on $90 \mathrm{MO}$ trees across the 10 departments of Haiti and submitted to statistical analysis using SPSS. One-way ANOVA results revealed that significant difference was noted among accessions ( $p<0.05$ ). NBP varied from 32 to 163 (Table 1 ). 
Six of the 10 departments showed NBP $>50$. The two most important NBP were detected mainly in materials from Grand'Anse and South departments with respectively 162.89 and 104.67. Similar results suggest considerable phenotypical diversities among accessions. By addition, NPB varied from 3 to 18 per department. MO accessions from Grand'Anse were significantly different from the others ( $p<0.05)$. No significant difference was noted between South and Southeast departments (p>0.05). Similar findings are consistent with those of (Ali et al., 2010). PL of tested MO are ranging from 26 to $39 \mathrm{~cm}$. Almost 50\% of accessions revealed PL $30 \mathrm{~cm}$. Accessions from Grand'Anse, South and North showed no significant difference ( $p$ > 0.05). Findings of the currents survey regarding PL are differing from that of Osman and Abohassan, (2012). This difference could be due to the origin of MO accessions. Environmental variation could affect significantly traits of materials including $\mathrm{MO}$ trees (Gomaa and Picó, 2011; Raja et al., 2013; Galloway, 2001). Five classes of $\mathrm{MO}$ were detected by putting emphasis on PC. These classes were identified by the different letters a, b, c, d and e. CP of accessions varied from 7 to $9 \mathrm{~cm}$. No significant differences were noted among South, Grand'Anse, Artibonite and Center accessions, which suggest possible homogeneity inside these materials regarding CP. Similarly, NGP are ranging from 13-18. Almost $40 \%$ of accessions showed NGP 17 , which is congruent with (Ayerza, 2011). Maximal (17.96) and minimal (13.42) NGP were respectively noted in materials from South and Grand'Anse.MlG of Haitian MO is ranging from 0.27 and $0.90 \mathrm{~g}$. MlG from South material represent three times of that of Artibonite and North. Present findings support data reported by (Foidl et al., 2001). Ml00G of materials also varied from 27.81 to 89.79 g. Sixty $\%$ of the $\mathrm{MO}$ accessions are > $30 \mathrm{~g}$, which is consistent with (Osman and Abohassan, 2012). Little variability was detected among Haitian MO regarding GY. GY of accessions are ranging from 0.23 to $3.26 \mathrm{t} / \mathrm{ha}$. More than $80 \%$ of MO accessions showed GY>0.50 t/ha. Materials from Grand'Anse and South departments are largely more grain yielded than others ( $p<0.05$ ). GY of South accessions represent almost 8 times of that of Artibonite. The current study is the first one reported data regarding MO grain yield in Haiti. Conducting others studies for comparing current findings is evident.

Results obtained for MC are listed on Table 2. More than $64 \%$ (18 of 28) of couples resulted from the analyzed traits are related $(p<0.05)$. Positive dependence was noted among all traits, which suggest that an increasing of one of these traits correspond systematically to the increasing of the predictive characters. Fifty $\%$ of traits are correlated at $p<0.001$. The maximal correlation of couples was detected between MlG and Mlo0G ( $\rho=0.99, p<0.001)$. Suggesting the presence of more than $98 \%\left(\mathrm{R}^{2}=0.9801\right)$ of confidence to obtain Ml00G by using MlG as predictor which is consistent with (Dabre et al., 2016; Allam et al., 2018). GY was correlated with all the seven other characters registered, confirming the total dependence of GY to other MO traits in Haiti (Rafiq et al., 2010). The strongest correlation of GY was mainly noted with NBP $(\rho=0.74$; $\mathrm{p}$ $0.001)$ and NPB $(\rho=0.60 ; p<0.001)$. Similar finding is not very promising for $\mathrm{MO}$ cultivation in Haiti because habitually farmers select grain based on the seed weight. Necessity to assure the formation of farmers with regard to other traits for selection becomes very evident. On the other hand, $36 \%$ of the traits were noted correlated, suggesting the impossibility to use one of these characters as predictor in a breeding model. Maybe all these traits are related with other agricultural practices which were not investigated in the current survey. Similar findings were reported in studies conducted on cereals (Dhawi et al., 2017).

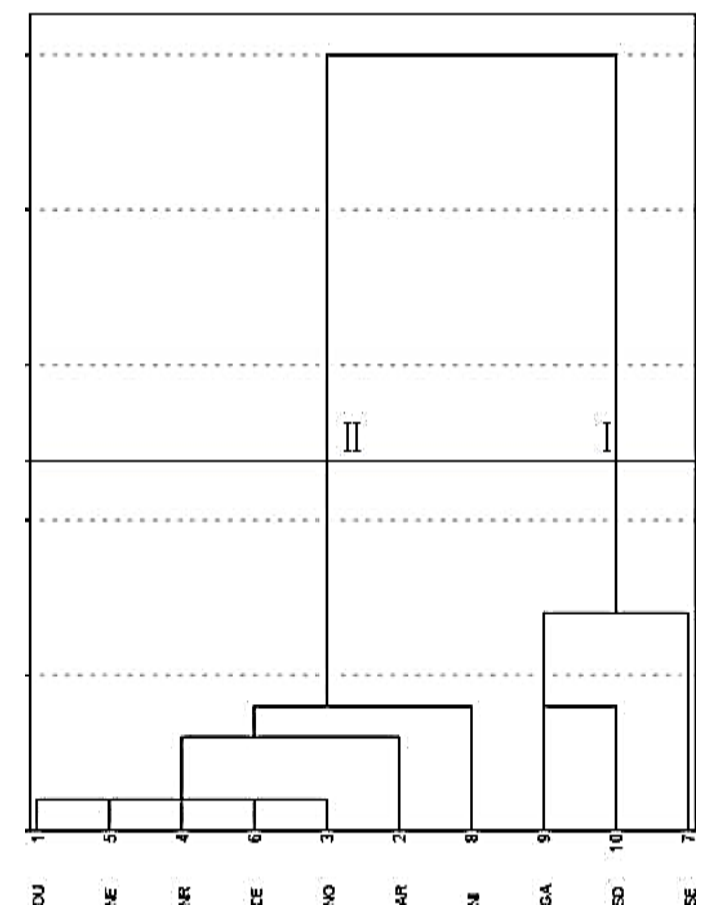

Figure 1:Dendrogram resulted from Clustering Analysis. OU: West, NE: Northeast, NR: North, CE: Center, NO: Northwest, AR: Artibonite, NI: Nippes, GA: Grand'Anse, SO: South, and SE: Southeast.

Figure 1 shows the results obtained for clustering analysis. Haitian MO was divided into two separated groups (GI and GII). GI is mainly constituted of 3 departments and GII with the others seven accessions. MO of GII is divided into three subgroups of one, one and 5 accessions. Materials constituting the first subgroup with the 5 accessions are from West, North, Northwest, Northeast and Center departments. Present results suggest that all 
Northern Haitian accessions are from a common ancestor. Maybe one of these materials was transferred in the West and Center department by habitually exchange of materials detected among Haitian farmers. Accessions from Nippes and Artibonite departments are closer to the first GI compared with Northern ones. Materials from South, Grand'Anse and Southeast are forming GI. Similar result confirming the homogeneity detected between South and Grand'Anse departments suggesting by the ANOVA results. Maybe materials from Grand'Anse, South and Southeast departments are from, as the northern ones, a common parent, which is different from the others. Historically, after the Independence (1804), in 1806 year, Haiti was divided into two separate governments: North and South. The South including South department, Southeast and Grand'Anse was governed by Alexandre Pétion and the North one including North department, Northeast, Northwest and Center was governed by Henri Christophe. Agricultural activities and exchange of materials are commonly conducted among farmers inside the same department or Government, this could be resulted from this situation called in Haiti " La scission d'Haiti". The largest morphological variation was noted in accessions from West and Southeast departments, which confirm also the variability among Haitian MO. Variability of $\mathrm{MO}$ was documented prior by (Hassanein and $\mathrm{Al}$ Soqeer, 2017). Predominance of variability among accessions could suggest presence of genes with great agronomic importance in Haitian MO (Shi et al., 2018). MO is used in Medicine, Nutrition, water purification and environment protection (Díaz et al., 2018; de Paula et al., 2018; Formentini-Schmitt et al., 2018).

\section{CONCLUSION}

MO is a plant with great medical and nutritional properties. It is cultivated in subtropical and tropical areas including Haiti. Data relative to Haitian MO are inexistent. In the current survey results revealed that Haitian MO grain yield are ranging from 0.20 to $3.26 \mathrm{t} / \mathrm{ha}$. Materials from Southern and Northern are forming two separated clusters. Crossing materials from Southeast and West is well recommended in order to create possibly new accessions. Additional investigation regarding molecular classification is deeply required for better understanding the genetic diversity of Haitian MO.

\section{ACKNOWLEGMENTS}

Deep thanks to LaugeneCleanta, DieunisAusting and Marcus Garvey Senatus for their contribution and assistance during sampling and laboratory measurement.

\section{REFERENCES}

Ali E.N., Muyibi S.A., Salleh H.M., Alam M.Z. and Salleh M.R.M. (2010). Production of natural coagulant from Moringa oleifera seed for application in treatment of low turbidity water, Journal of Water Resource and Protection., 2(03): 259.https://doi.org/10.4236/jwarp.2010.23030

Allam A., Tirichine A., Madani H. and Benlamoudi W. (2018). Variabilité morphologique du sorgho (Sorghum bicolor L. Moench), cultivé dans la vallée d'Oued Righ (Sud-est Algerien). Lebanese Science Journal, 19(1): 10.https://doi.org/10.12816/0045856

Anwar F., Latif S., Ashraf M. and Gilani A.H. (2007). Moringa oleifera: a food plant with multiple medicinal uses. Phytother Res: An International Journal Devoted to Pharmacological and Toxicological Evaluation of Natural Product Derivatives.21(1): 17-25. https://doi.org/10.1002/ptr.2023

Anwar F., Zafar S.N. and Rashid U. (2006). Characterization of Moringa oleifera seed oil from drought and irrigated regions of Punjab, $\begin{array}{llll}\text { Pakistan. } & \text { GrasasAceites, } & \text { 57(2): }\end{array}$ https://oi.org/10.3989/gya.2006.v57.i2.32

Aristil J. (2018). Integrated approaches to agriculture in developing country: Haiti. PhD thesis, University of Milan, Milan, p 174. https://doi.org/10.4314/ijbcs.vl3i2.12

Aristil J. (2019).Effets de trois types de fertilisants sur les paramètresvégétatifs et productifs du sorghoenHaïti. Int. J. Biol. Chem. Sci.,13(2): 720-726. DOI: https://dx.doi.org/10.4314/ijbcs.vl3i2.12

Aristil J., Venturini G. and Spada, A. (2017). Occurrence of Toxigenic Fungi and Aflatoxin Potential of Aspergillus spp. Strains Associated with Subsistence Farmed Crops in Haiti. J Food Protect, 80(4): 626-631. https://doi.org/10.4315/0362-028x.jpp-16-278

Aristil J., Venturini G., Maddalena G., Toffolatti S. L. and Spada A. (2020). Fungal contamination and aflatoxin content of maize, moringa and peanut foods from rural subsistence farms in South Haiti. J Stored Prod Res., 85: 101550. https://doi.org/10.1016/j.jspr.2019.101550

Ayerza R. (2011). Seed yield components, oil content, and fatty acid composition of two cultivars of moringa (Moringa oleifera Lam.) growing in the Arid Chaco of Argentina. Ind Crop Prod., 33(2): 389-394. https://doi.org/10.1016/j.indcrop.2010.11.003

Boucher J. (2006). Oleaginous plant seeds and seed by-products for water treatment. Chemical Engineering. Lausanne, École Polytechnique Fédérale de Lausanne (EPFL). PhD, 247. https://doi.org/10.24295/cpsstpea.2019.00017

Chumark P., Khunawat P., Sanvarinda Y., Phornchirasilp S., Morales N. P., Phivthong-ngam L. and Klai-upsorn S.P. (2008). The in vitro and ex vivo antioxidant properties, hypolipidaemic and antiatherosclerotic activities of water extract of Moringa oleifera Lam. leaves. I Ethnopharmacol., 116(3): 439-446. https://doi.org/10.1016/j.jep.2007.12.010

Corp IBM. (2013). IBM SPSS statistics for windows, version 22.0. Armonk, NY: IBM Corp.

Crossa J. and Franco J. (2004). Statistical methods for classifying genotypes. Euphytical37(1): 19-37. https://doi.org/10.1023/b:euph.0000040500.86428.e8

Dabre A., Hien E., Some D. and Drevon J.J. (2016).Impacts des pratiques culturales sur la production du sorgho (Sorghum bicolor L.) et du niébé (Vignaunguiculata (L.) Walp.) et sur le bilan partiel de l'azote sous niébé au Burkina Faso. Int. J. Biol. Chem. Sci.,, 10(5): 22152230.https://doi.org/10.4314/ijbcs.vl0i5.22

Dahiru D., Onubiyi J.A. and Umaru H.A. (2006). Phytochemical screening and antiulcerogenic effect of Moringa oleifera aqueous leaf $\begin{array}{lllll}\text { extract. Afr J TraditComplem., } & \text { 3(3): } & \text { 70-75. }\end{array}$ https://doi.org/10.4314/ajtcam.v3i3.31167

De Paula H. M., de Oliveira Ilha M.S., Sarmento A.P. and Andrade L.S. (2018). Dosage optimization of Moringa oleifera seed and traditional 
chemical coagulants solutions for concrete plant wastewater treatment. J Clean Prod., (17)4: 123-132. https://doi.org/10.1016/j.jclepro.2017.10.311

Dhawi F., Datta R. and Ramakrishna W. (2017). Proteomics provides insights into biological pathways altered by plant growth promoting bacteria and arbuscular mycorrhiza in sorghum grown in marginal soil. Bba-Proteins $\quad$ Proteom., $\quad$ 1865(2): 243-25l. https://doi.org/10.1016/j.bbapap.2016.11.015

Díaz J.J.F., BallutDajud G. and Miranda J. P. R. (2018). Influence of storage time of Moringa oleifera seed on the coagulant activity efficiency for raw water treatment. Indian Journal of Science and Technology., 8(1).

Foidl N., Makkar H.P.S. and Becker K.(2001).Potentiel de Moringa oleifera en agriculture et dans l'industrie. Potentiel de développement des produits de Moringa. Dar es-Salaam, Tanzanie, du 29 octobre au 2 Novembre 2001.

Formentini-Schmitt D.M., Fagundes-Klen M.R., Veit M.T, Palácio S. M., Trigueros D.E.G., Bergamasco R. and Mateus G.A.P. (2018). Potential of the Moringa oleifera saline extract for the treatment of dairy wastewater: application of the response surface methodology. Environ Technol., 1-10. https://doi.org/10.1080/09593330.2018.1440012

Galloway L.F. (2001). The effect of maternal and paternal environments on seed characters in the herbaceous plant Campanula americana (Campanulaceae). Am J Bot., 88(5): 832-840. https://doi.org/10.2307/2657035

Gigon A., Matos A.R., Laffray D., Zuily-Fodil Y. and Pham-Thi A.T. (2004). Effect of drought stress on lipid metabolism in the leaves of Arabidopsis thaliana (ecotype Columbia). Ann Bot-London., 94(3): 345 351.https://doi.org/10.1093/aob/mchl50

Gomaa N.H. and Picó F. X. (2011). Seed germination, seedling traits, and seed bank of the tree Moringa peregrina (Moringaceae) in a hyper-arid environment. Am J Bot., 98(6): 1024-1030. https://doi.org/10.3732/ajb.1000051

Hassanein A.M.A. and Al-Soqeer A.A. (2017). Morphological and genetic diversity of Moringa oleifera and Moringa peregrina genotypes. Hortic Environ Biote, 1-11. https://doi.org/10.1007/s13580-018-0024-0

Kwon S.H. and Torrie J.H. (1964). Heritability and interrelationship among traits of two soybean populations. Crop science.,4(2): 196-198. https://doi.org/10.2135/cropscil $964.0011183 \times 000400020023 x$

Leone A., Spada A., Battezzati A., Schiraldi A., Aristil J. and Bertoli S. (2015). Cultivation, genetic, ethnopharmacology, phytochemistry and pharmacology of Moringa oleifera leaves: an overview. Int J Mol Sci., 16(6): 12791-12835. https://doi.org/10.3390/ijms17122141

Leone A., Spada A., Battezzati A., Schiraldi A., Aristil J. and Bertoli S. (2016). Moringa oleifera seeds and oil: Characteristics and uses for human health. Int J MolSci., 17(12): 2141. https://doi.org/10.3390/ijms17122141

MarreroDelange D., Vicente Murillo R., Canavaciolo V.L.G. and Amaro J.G. (2014).Composición de ácidosgrasosdelaceite de las semillas de Moringa oleífera que crece en La Habana, Cuba. RevistaCubana de PlantasMedicinales., $19(2)$ : https://doi.org/10.3989/gya.1994.v45.i3.988
Mendieta-Araica B., Spörndly E., Reyes-Sánchez N., SalmerónMiranda F. and Halling M. (2013). Biomass production and chemical composition of Moringa oleifera under different planting densities and levels of nitrogen fertilization. Agroforest Syst., 87(1): 81-92. https://doi.org/10.1007/s10457-012-9525-5

Morton J.F. (1991). The horseradish tree, Moringa pterygosperma (Moringaceae) - a boon to arid lands?.Econ Bot., 45(3): 318-333. https://doi.org/10.1007/bf02887070

Ogunsina B.S., Indira T.N., Bhatnagar A.S., Radha C., Debnath S. and Krishna A.G. (2014). Quality characteristics and stability of Moringa oleifera seed oil of Indian origin. J Food Sci Techno., 51(3): 503-510. https://doi.org/10.1007/s13197-011-0519-5

Olson M.E. and Carlquist S. (2001). Stem and root anatomical correlations with life form diversity, ecology, and systematics in Moringa (Moringaceae). Bot J Linn Soc., 135(4): 315-348. https://doi.org/10.1111/j.10958339.2001.tb00786.x

Osman H.E. and Abohassan A. A. (2012). Morphological and analytical characterization of Moringa peregrina populations in western Saudi Arabia. Int J TheorAppl Sci., 4(2): 174-184.

Ouazine S., Belala H. and Hassissene N.E. (2017).Propriétés fonctionnelles de poudre de feuilles de Moringa oleifera.

Price M.L. (1985). The moringa tree. Educational Concerns for Hunger Organization (ECHO) Technical Note.

Rafiq C. M., Rafique M., Hussain A. and Altaf M. (2010). Studies on heritability, correlation and path analysis in maize (Zea mays L.). J. Agric. Res., 48(1): 35-38.

Raja S., Bagle B.G. and More T.A. (2013). Drumstick (Moringa oleifera Lamk.) improvement for semiarid and arid ecosystem: Analysis of environmental stability for yield. J. Plant Breed. Crop Sci., 5: 164-170. https://doi.org/10.5897/jpbcs12.029

Shahzad U., Khan M.A., Jaskani M.J., Khan I.A. and Korban S.S. (2013). Genetic diversity and population structure of Moringa oleifera. Conserv Genet., 14(6): 1161-1172.https://doi.org/10.1007/s10592-013-0503-x

Shi Y., Wang X. and Huang A. (2018). Proteomic analysis and foodgrade enzymes of Moringa oleifer Lam. a Lam. flower. Int J BiolMacromol., 115: 883-890. https://doi.org/10.1016/j.jibiomac.2018.04.109

Teixeira E.M.B., Carvalho M.R.B., Neves V.A., Silva M.A. and ArantesPereira L. (2014). Chemical characteristics and fractionation of proteins from Moringa oleifera Lam. leaves. Food Chem., 147: 51-54. https://doi.org/10.1016/j.foodchem.2013.09.135

Thurber M.D. and Fahey J.W. (2009). Adoption of Moringa oleifera to combat under-nutrition viewed through the lens of the "Diffusion of Innovations" theory. Ecol Food Nutr., 48(3): 212-225. https://doi.org/10.1080/03670240902794598

Yang R.Y., Chang L.C., Hsu J.C., Weng B.B., Palada M.C., Chadha M. L. and Levasseur V. (2006). Nutritional and functional properties of Moringa leaves-From germplasm, to plant, to food, to health. Moringa leaves: Strategies, standards and markets for a better impact on nutrition in Africa. Moringanews, CDE, CTA, GFU. Paris. 
Table 1: Results of Variance Analysis

\begin{tabular}{|c|c|c|c|c|c|c|c|c|}
\hline \multicolumn{9}{|c|}{ Characters } \\
\hline Departments & NBP & NPB & PL & PC & NGP & $\mathrm{MlG}$ & $\begin{array}{c}\text { Ml00 } \\
\text { G }\end{array}$ & GY \\
\hline South & $\begin{array}{c}104.67 \\
b\end{array}$ & $7.92 b c$ & $38.19 d$ & $8.65 e$ & $17.96 \mathrm{~d}$ & $0.90 b$ & $89.73 b$ & $2.37 \mathrm{~b}$ \\
\hline Southeast & $\begin{array}{c}73.44 a \\
b\end{array}$ & $9.77 \mathrm{c}$ & $30.31 \mathrm{bc}$ & $7.22 \mathrm{abc}$ & 15.6labcd & $0.41 \mathrm{a}$ & $41.12 a$ & $0.99 a$ \\
\hline Grand'Anse & $\begin{array}{c}162.89 \\
\text { c }\end{array}$ & 18.0ld & $36.47 d$ & $8.28 \mathrm{cde}$ & $17.56 \mathrm{~d}$ & $0.37 \mathrm{a}$ & $36.42 \mathrm{a}$ & $3.26 b$ \\
\hline West & $\begin{array}{c}57.33 a \\
b\end{array}$ & $3.44 \mathrm{a}$ & $32.31 \mathrm{c}$ & 7.64abcd & 16.3labcd & $0.27 \mathrm{a}$ & $27.86 a$ & $0.90 \mathrm{a}$ \\
\hline Artibonite & $32.67 \mathrm{a}$ & $7.56 b c$ & $26.64 a$ & $7.04 \mathrm{ab}$ & $14.78 \mathrm{abc}$ & $0.28 \mathrm{a}$ & $28.31 \mathrm{a}$ & $0.23 a$ \\
\hline Center & $54.01 \mathrm{a}$ & $8.78 b c$ & $28.23 \mathrm{ab}$ & 8.5lde & $16.64 \mathrm{bcd}$ & $0.28 \mathrm{a}$ & $27.81 \mathrm{a}$ & $0.56 a$ \\
\hline North & $52.11 \mathrm{a}$ & $5.56 \mathrm{ab}$ & $36.47 d$ & 8.14 bcde & $17.25 \mathrm{~cd}$ & $0.29 a$ & $29.14 \mathrm{a}$ & $0.66 a$ \\
\hline Northeast & $\begin{array}{c}62.89 a \\
b\end{array}$ & $9.78 \mathrm{c}$ & $29.44 a b c$ & $7.03 a$ & $17.28 \mathrm{~cd}$ & $0.28 \mathrm{a}$ & $28.28 \mathrm{a}$ & $0.89 a$ \\
\hline Northwest & $33.50 \mathrm{a}$ & $8.01 b c$ & $26.25 a$ & 7.80abcde & $13.42 \mathrm{a}$ & $0.30 \mathrm{a}$ & $30.21 \mathrm{a}$ & $0.28 \mathrm{a}$ \\
\hline Nippes & $48.22 \mathrm{a}$ & $6.01 \mathrm{abc}$ & $29.28 \mathrm{abc}$ & 7.74abcde & $14.64 \mathrm{ab}$ & $0.30 a$ & $29.70 \mathrm{a}$ & $0.78 \mathrm{a}$ \\
\hline
\end{tabular}

NBP: number of branches par plant; NPB: number of pods per branch; PC: Pod circumference (cm); NGP: number of grains per pod; MlG: mass of 1 grain (g); Ml00G: mass of 100 grains (g); GY: grain yield ( $\mathrm{t} / \mathrm{ha}$ ). Characters with different letter are significantly different at $\mathrm{p}<0.05$.

Table 2: Correlation matrix resulted from the registered characters

\begin{tabular}{|c|c|c|c|c|c|c|c|c|}
\hline & NBP & NPB & PL & $\mathrm{PC}$ & NGP & $\mathrm{MIG}$ & M100G & GY \\
\hline NBP & 1 & $0,79 * * *$ & $0,14^{* *}$ & $0,12^{*}$ & $0,16^{* *}$ & $-0,13^{\mathrm{NS}}$ & $-0,01^{\mathrm{NS}}$ & $0,74 * * *$ \\
\hline NPB & & 1 & $0,68^{\mathrm{NS}}$ & $0,02^{\mathrm{NS}}$ & $0,17^{* *}$ & $0,02^{\mathrm{NS}}$ & $-0,2^{\mathrm{NS}}$ & $0,60^{* * *}$ \\
\hline PL & & & 1 & $0,18 * *$ & $0,50 * * *$ & $0,71^{\mathrm{NS}}$ & $0,14 * *$ & $0,23 * * *$ \\
\hline $\mathrm{PC}$ & & & & 1 & $0,21^{* * *}$ & $0,71^{\mathrm{NS}}$ & $0,07^{\mathrm{NS}}$ & $0,11^{*}$ \\
\hline$\overline{\mathrm{NGP}}$ & & & & & 1 & $-0,09^{\mathrm{NS}}$ & $-0,10^{\mathrm{NS}}$ & $0,16^{* *}$ \\
\hline$\overline{M l G}$ & & & & & & 1 & $0,99 * * *$ & $0,55^{* * *}$ \\
\hline Ml00G & & & & & & & 1 & $0,55^{* * *}$ \\
\hline GY & & & & & & & & 1 \\
\hline
\end{tabular}

NBP: number of branches par plant; NPB: number of pods per branch; PC: Pod circumference (cm); NGP: number of grains per pod; MlG: mass of 1 grain (g); Ml00G: mass of 100 grains (g); GY: grain yield (t/ha). *: p<0. 05; **: p<0.01; ***: p< 0.001 and, NS: not significant (p>0.05).

(c) 2020| Published by Plantae Scientia 